\title{
Ethnologies
}

\section{U.S. Consideration of the Intangible Cultural Heritage Convention}

\section{Richard Kurin}

Volume 36, numéro 1-2, 2014

Patrimoine culturel immatériel

Intangible Cultural Heritage

URI : https://id.erudit.org/iderudit/1037612ar

DOI : https://doi.org/10.7202/1037612ar

Aller au sommaire du numéro

Éditeur(s)

Association Canadienne d'Ethnologie et de Folklore

ISSN

1481-5974 (imprimé)

1708-0401 (numérique)

Découvrir la revue

Citer cet article

Kurin, R. (2014). U.S. Consideration of the Intangible Cultural Heritage

Convention. Ethnologies, 36(1-2), 325-358. https://doi.org/10.7202/1037612ar
Résumé de l'article

L'UNESCO, l'Organisation des Nations unies pour l'éducation, la science et la culture, a voté à une majorité écrasante, lors de la réunion biennale de sa Conférence générale à Paris, le 17 octobre 2003, en faveur de l'adoption de la nouvelle Convention internationale pour la sauvegarde du patrimoine culturel immatériel. Cette Convention est devenue une loi internationale le 30 avril 2006. À la fin de l'année 2006, elle avait été ratifiée ou acceptée par 68 pays ; aujourd'hui elle est quasiment universellement acceptée, plus de 160 nations ayant ratifiéé la Convention. Lors de la session de 2003, quelque 120 nations-membres avaient voté en faveur de la Convention ; d'autres y ont souscrit par la suite. Personne n'a voté contre ; seuls quelques rares pays se sont abstenus - dont l'Australie, le Canada, le Royaume-Uni et les États-Unis. Au sein de ces pays, on discute encore de savoir s'il faut ou non ratifier ce traité. Dans cet article, à titre officieux, l'auteur examine la Convention et la position du gouvernement américain à son sujet, exposant les raisons du retrait de son soutien à celle-ci en 2003, relatant la façon dont les délibérations se sont déroulées depuis, et cherchant à déterminer si oui ou non les États-Unis finiront par accepter ce traité.
Ce document est protégé par la loi sur le droit d'auteur. L'utilisation des services d’Érudit (y compris la reproduction) est assujettie à sa politique d'utilisation que vous pouvez consulter en ligne.

https://apropos.erudit.org/fr/usagers/politique-dutilisation/ 


\title{
U.S. Consideration of the Intangible Cultural Heritage Convention
}

\author{
Richard Kurin \\ Smithsonian Institution
}

UNESCO, the United Nations Educational, Scientific, and Cultural Organization, voted overwhelming at the biennial meeting of its General Conference in Paris on October 17, 2003 to adopt a new International Convention for the Safeguarding of Intangible Cultural Heritage. ${ }^{1}$

That convention became international law on April 30, 2006. By the end of 2006 it had been ratified or accepted by 68 countries; today, that number is approaching universal acceptance with 161 nations having acceded to the convention. ${ }^{2}$ The purpose of this multilateral treaty is to help local cultural traditions around the world survive and even flourish in the face of globalization. It calls for national governments to inventory their "intangible cultural heritage" - living traditions of music, narrative, craftsmanship, forms of folk knowledge, rituals and celebrations- and devise action plans for safeguarding them. The convention obliges national agencies to work closely with cultural practitioners on research and documentation projects, educational programs, national honors, protective laws, and economic development plans, so that the traditions are kept alive and transmitted to the next generation.

Since its passage, and as predicted at the time by its advocates, the convention has provided a multilateral framework for national governments to conceptualize and deal with living cultural heritage.

1. For the complete English text of the convention, see UNESCO, International Convention for the Safeguarding of Intangible Cultural Heritage, Paris 17 October 2003. http://www.unesco.org/culture/ich/index.php?lg=en\&pg=00006 (retrieved July 6, 2014).

2. For a full list of states parties, see the UNESCO website at http://www.unesco. org/eri/la/convention.asp? $\mathrm{KO}=17116 \&$ language $=\mathrm{E}($ retrieved July 6, 2014). 
At the 2003 session, some 120 nation-members voted for the convention; scores more registered their support subsequently. No one voted against it; only a handful of nations abstained-Australia, Canada, the United Kingdom, and the United States among them (Kurin, 2003). Within some of those nations, debate over whether to ratify the treaty continues.

In this paper, I consider the convention and unofficially examine the U.S. government position with regard to why support for it was withheld in 2003, how deliberations have proceeded since then, and whether or not the U.S. might ultimately accept the treaty.

\section{The U.S., UNESCO, and Culture}

The U.S. was one of the founding members of UNESCO in 1945, and a number of Americans such as Eleanor Roosevelt, Archibald MacLeish, and Margaret Mead played important roles in its early days. UNESCO, along with the United Nations, the World Bank and other institutions, was part of a new world system emerging after World War II, aimed at preserving peace, stabilizing nations, and encouraging modernity. UNESCO programs supported various initiatives consistent with U.S. interests, among them the concept of human rights, programs offering free, universal public education and those encouraging scientific work and international cooperation. In the cultural sphere, the U.S. early on supported UNESCO's work in the development of international conventions or treaties concerned with the protection of copyright and related creative rights and the protection of cultural property in cases of armed conflict. The U.S. was a major force behind one of UNESCO's most important and popular initiatives, the 1972 Convention Concerning the Protection of the World Cultural and Natural Heritage. This established what is commonly called the world heritage list, and sought to provide international recognition, legal protection and financial resources to preserve significant archaeological sites, ancient and historical monuments and buildings, and important natural areas and landscapes.

In 1984, the U.S. government, under then president Ronald Reagan, pulled out of UNESCO. The U.S. had a host of problems with the organization, claiming that it was instituting a somewhat pernicious "new world information order" antithetical to freedom. While founded to encourage human rights, and open thinking free societies, the Reagan administration charged that UNESCO was becoming an organ of 
propaganda, restricting the free flow of information, and abetting increased state control over people's lives. In the U.S. view, UNESCO had an inflated, patronage-run bureaucracy, was inefficient and wasteful, and promoted socialist and third-world ideology over practical, on-the-ground results.

Absent U.S. official participation and its budgetary contribution, UNESCO continued its work. U.S. scientific and cultural organizations still cooperated with UNESCO projects directly, such as in the Man in the Biosphere Program, and indirectly, through various international professional associations affiliated with the multilateral organization.

\section{The U.S. Role in Moving Toward the Convention}

In the cultural arena, UNESCO made slow progress on addressing the concerns of several member states that some type of normative instrument be developed to deal with traditional culture or folklore (Sherkin, 2001; Aikawa, 2001). Bolivia had raised such a concern in the debate over the consideration of the 1972 world heritage convention. Several nations, inspired by Japan's government model had developed quite extensive and intricate programs to recognize living cultural heritage, significant cultural activities, practices, and human cultural treasures. In 1989 UNESCO developed a formal Recommendation on the Safeguarding of Traditional Culture and Folklore. ${ }^{3}$ This document suggested that nations research and document their folklore, enhance archives, produce festivals and otherwise promote knowledge about their cultural traditions to their citizens. In international legal parlance, a recommendation is a "soft" instrument-it suggests certain actions but lacks any official, legal obligation to comply with its provisions. The recommendation was not a big priority within UNESCO, and it was not well publicized among member nations.

In UNESCO, responsibility for the recommendation and related programs in music and language preservation at that time rested with Noriko Aikawa, a Japanese art historian working in the area of cultural exchange. At the request of UNESCO, the Japanese Ministry of Foreign Affairs in 1993 created a fund called The Japanese Funds-in-Trust for the Preservation and Promotion of the Intangible Cultural Heritage. The term "intangible cultural heritage" was a translation of the Japanese "mukei

3. For the complete English text of the recommendation, see Recommendation on the Safeguarding of Traditional Culture and Folklore, Paris 15 October 1989. http:// portal.unesco.org/en/ev.phpURL_ID $=13141 \&$ URL_DO=DO_TOPIC\&URL_ SECTION=201.html (retrieved July 6, 2014). 
bunkazi." 4 The fund and a program called Safeguarding and Promoting of Intangible Cultural Heritage were established within UNESCO. This developed into the UNESCO Section on Intangible Cultural Heritage and Aikawa became its head.

With sponsorship from the fund, UNESCO held a series of national and regional meetings in East Asia on intangible cultural heritage. From 1995-99, it sponsored regional meetings around the world to examine the work of countries in the realm of folklore and traditional culture and the impact, if any, of the 1989 recommendation (Seeger, 2001). Reports from delegates to these meetings and a questionnaire sent to all UNESCO member states disclosed that the recommendation had not really resonated with home governments or organizations and had not occasioned a spate of activity (Kurin, 2001).

By the late 1990s, UNESCO sought to inject new energy into the recommendation by partnering with the Smithsonian Institution for an international conference. The impetus was a working relationship between Aikawa and Anthony Seeger. Seeger served in the leadership of the International Council of Traditional Music, affiliated with UNESCO, and advised on the publication of recordings from the UNESCO Collection of Traditional Music of the World. An internationally renowned musical anthropologist and nephew of the famed folk singer Pete Seeger, Anthony Seeger then served as the Director of Smithsonian Folkways Recordings in the Smithsonian Center for Folklife and Cultural Heritage. While the Smithsonian agreed to organize the UNESCO working conference in Washington, it would not be an "official" one, since the Smithsonian is a unique public trust but not an agency of the U.S. federal government. Still, the Smithsonian Center secured the support of the U.S. Department of State observer mission to UNESCO in holding the conference, and in addition to its own and UNESCO funds, garnered financial support from the U.S, Department of State, Japan's Ministry of Foreign Affairs, the National Endowment for the Arts and the Rockefeller Foundation (Seitel 2001c). Mounir Bouchenaki, UNESCO Assistant Director General for Culture and I, then in my capacity as Director of the Smithsonian Center for Folklife and Cultural Heritage, hosted the conference. Quite sensitive to the fact that the U.S. was not a member of UNESCO, a written statement from UNESCO's Director General Federico Mayor read at the inception of the conference linked Smithsonian and UNESCO goals and activities, and

4. For information on the Japanese fund see http://www.mofa.go.jp/policy/culture/ heritage/coop/index.html (retrieved November 27, 2006). 
signaled common concern with the safeguarding of traditional culture by recognizing that former Smithsonian Center Director Ralph Rinzler was active in the U.S. National Commission for UNESCO and was a tireless worker for cultural democracy (Mayor, 2001).

The context for the international discussion of cultural policy in 1999 was considerably different than it had been a decade earlier. The energy for re-investing and reformulating the ideas found in the 1989 recommendation gathered force in the 1990s with the almost universal realization of the impact of globalization around the world as reported in UNESCO's publication of the World Commission on Culture and Development study Our Creative Diversity (1997) and as noted by many others (Serageldin, 1998; Graves, 2005). As Bouchenaki (2001: 4) noted in his opening address:

Intangible [cultural heritage], like the physical and natural heritage, is itself vulnerable and, as such, is at risk of being swept away by the global trend towards homogenization and the pressures of a market economy that continually applies commercial standards to aspects of life which cannot be reduced to economic profit and loss. . . Promoting diversity would certainly slow down the process of global uniformity, which seems, paradoxically, to lead to global anonymity.

Local, regional, even national cultures were perceived as being under threat by forces of modernization and the spread of a global, commerciallybased culture largely identified with the United States. The ubiquity of television, movies, home videotape players, radio, tape and CD players, challenged the vitality of local performance, musical, dramatic, and story telling traditions. Imported manufactured goods replaced traditional artisanal and handcrafted goods in most marketplaces. The use of English in newspapers, books and other media-as well as in business practice, academia, and science was marginalizing other, local and national languages. American-based fast-food stores were competing with local restaurants, challenging ideas of culinary culture.

The impact was not just in so-called third world countries. Europeans found themselves inundated with new cultural forms viewed as challenging their own national and urbane traditions. Japanese and Koreans were quite attuned to the needs of preserving their cultures in the face of American influence after World War II and the Korean War. Canadians, Mexicans, elites in South America, northern and other parts of Africa, and in the Pacific were cognizant of the potential problem-holding their own states together culturally while facing new, popular forms of culture from abroad. 
Whereas only a decade earlier with the formulation of the recommendation, the importance of home grown cultural expressions might have been looked at with a bit of quaint nostalgia and pro forma recognition, these traditions now came to the fore as a source of the continued identity of national polities.

These traditions also had an economic dimension. Globalization meant increased tourism, particularly cultural tourism, around the planet. Local song, music, cuisine, and markets had their charm and lured tourist dollars. More so, they could also be exploited and expropriated in world markets. Songs sung and melodies played by local people could be learned by foreign artists, adapted and earn millions played for exogenous audiences (Seeger, 2004). Forms of indigenous and folk knowledge—of flora, of curative medicines, and regimens-nurtured by generations of local practitioners and exemplars, could be abstracted from local contexts by agents of pharmaceutical and medical companies, taken to the West, and even patented, developed and sold —with little benefit returning to the communities which nurtured such knowledge. From an economic perspective, while such forms of traditional culture may not have been seen as especially valuable in the recommendation, they emerged in the late 1990s as cultural property and assets worthy of investment within country, and legal protection from others.

The Smithsonian-UNESCO Washington conference in 1999 was purposely staged at the time of the annual Smithsonian Folklife Festivalwhich included hundreds of musicians, artists, craftspeople, cooks, story tellers, ritual specialists and other cultural exemplars from across the U.S. and around the world demonstrating their cultural traditions on the National Mall in Washington, D.C. amidst the Smithsonian's national museums and U.S. national monuments. This mirrored the Smithsonian's own point of view — what it called "cultural democracy" - that any effort to safeguard cultural traditions had to represent the broadest diversity of traditions, had to involve "the folk" as agents of their own culture, and had to encourage the living vitality of those traditions within their communities-not just as artifacts in museums or documents in archives (Kurin 1998). Papers prepared by Smithsonian professional staff in preparation for the conference summarized the results of regional assessment meetings, analyzed the impacts or lack thereof of the 1989 recommendation, and the conceptual weaknesses of its definitions and policy formulations. ${ }^{5}$

5. Prior to the Smithsonian conference, UNESCO convened eight regional 
Importantly, the Smithsonian insisted, and UNESCO agreed, that the conference should not only include cultural officials, academic and legal experts, but also leaders, exemplars, and advocates of cultural communities. Some 37 participants from 27 countries participated, with scores more as observers. ${ }^{6}$

Overall, the conference participants found the 1989 recommendation to be an ill-construed, ill-defined, "top-down," state-oriented instrument that defined traditional culture in essentialist, almost archival terms, and had little impact around the globe upon cultural communities and practitioners. The conference called for a more dynamic view of cultural traditions as "living" and enacted by communities. It envisioned a community-involved, participatory approach to safeguarding efforts and advised that a formal convention be considered (Seitel, 2001a; 2001c).

That plan for action came as Japanese diplomat Koichiro Matsuura was being appointed the new Director General of UNESCO. Matsuura generally regarded the development and promulgation of normative, standard-setting instruments - that is, international conventions or treaties — as perhaps the strongest and most desirable of actions UNESCO could take (Matsuura, 2004). Legally binding treaties gave UNESCO real power to effect changemore so than the panoply of conferences, publications, and discretionary program and projects that generally characterized the organization's roster

seminars to discuss the recommendation. These included conferences in June 1995 in Strážnice, Czech Republic for Central and Eastern European countries; in September 1997 in Mexico City for Latin America and the Caribbean; in February/ March 1998 in Tokyo for Asian countries; in September 1998 in Joensuu, Finland for Western European countries; in October 1998 in Tashkent for Central Asia and the Caucasus; in January 1999 in Accra for the African region; in February 1999 in Noumea, New Caledonia for the Pacific countries; and in May 1999 in Beirut for the Arab states. Papers prepared in advance included those by Kurin (2001), Seeger (2001), McCann et al. (2001).

6. Participants included UNESCO officials and staff, international cultural experts, cultural officials from a range of nations. Among community cultural advocates were Robyne Bancroft, an Aboriginal Australian (Goori) affiliated with the Australian National University in Canberra, Australia, Stepanida Borisova, a Yakut affiliated with the Ministry of Culture of the Sakha Republic in Russia, Russell Collier, a member of the Gitxsan Nation and part of the Strategic Watershed Analysis Team in Hazelton, British Columbia, Pualani Kanaka'ole Kanahele, an officer of the Edith Kanaka'ole Foundation in Hilo, Hawai'i, Miguel Puwainchir, a leader of the Schuar Achuar Federation and Mayor of the Huamboya Municipality, Province of Morona Santiago, Ecuador, Rajeev Sethi, and advocate of poor, disposed artists in Delhi, and principal of Rajeev Sethi Scenographers Pvt. Ltd. in India. 
of activities. In this case, given both his own proclivity and the interest of the Japanese government in the field, the idea of developing a formal treaty on cultural traditions was very attractive. Given that the terminology"folklore," "traditional culture," "oral heritage," "popular culture"—all had intellectual baggage that rendered them somewhat problematic in different areas of the world, Matsuura embraced the more neutral "intangible cultural heritage" as a desirable, technical term.

In taking office Matsuura heard complaints about the imbalance in UNESCO's cultural programs. The flagship UNESCO program on World Heritage sites privileged the north-where most of the ancient remains of large-scale classical civilizations-Greece, Rome, China, India, Egypt, Meso-America and Southeast Asia—persisted, and where most of the built monuments and memorials of historical grandeur where found. While there were certainly exceptions, many nations of the southern hemisphere lacked significant numbers of such physical, tangible sites. This of course did not mean countries of the "south" lacked culture, though viewing UNESCO programs, priorities, and maps, one might get that impression. By highlighting cultural traditions, oral heritage, or intangible cultural heritage, Matsuura pledged a corrective-a way of giving due recognition to the south (Matsuura, 2004).

The vehicle was a program called Proclamation of Masterpieces of the Oral and Intangible Heritage of Humanity. In 1997, UNESCO had organized an International Consultation on the Preservation of Popular Cultural Spaces in Marrakesh. The impetus came from Spanish writer Juan Goytisolo residing in Marrakesh. He, as well as many Moroccans, enjoyed and relished Marrakesh's famed Jemaa el-Fna Square as an active city plaza and meeting ground of cultural performance, story telling, culinary and artisanal culture. Yet this vibrant cultural space was endangered by vehicular traffic-largely tourist buses, and proposals by local leaders to turn it into a parking lot. Goytisolo and like-minded allies proposed to UNESCO the idea of providing international recognition for such ephemeral forms of cultural expression. In late 1999, UNESCO turned this initiative into a more general, global program (Aikawa, 2008). Rules were established, an international jury, chaired by Juan Goytisolo and including experts and high profile members, was selected. ${ }^{7}$ Member states were encouraged

7. In addition to Goytisolo, members of the founding jury included Hasan M. AlNaboodah (United Arab Emirates), Ambassador Azisa Benanni (Morocco), anthropology professor Georges Condominas (France), conservatory director Anzor Ermaichvili (Georgia), author diplomat Carlos Fuentes (Mexico), Hideki Hayashida (Japan), Ambassador Ugne Karvelis (Lithuania), anthropologist and 
to recommend significant intangible heritage to the UNESCO jury for inclusion on a prestigious list of "masterpieces" that would parallel the world heritage list. The program emphasized traditions and, ironically, their tangible expression, rather than the community processes that nurtured them and the practitioners and exemplars of the traditions. The program's criteria for selection also conflated cultural significance and endangerment to the consternation of the jury and other experts (Nas, 2002; Seeger, 2008). It almost assumed that all intangible cultural heritage the world over was seriously endangered due to globalization — which was clearly not the case. Nonetheless, the proclamation of the masterpieces-made at UNESCO headquarters and disseminated around the world through press releases, websites and other media proved exceedingly popular among UNESCO ambassadors and delegations. The first proclamation of masterpieces in 2001 included some 19 traditions from around the world —including, for example, the Oruro Festival (Bolivia), Kun Qu opera (China), polyphonic singing (Georgia), Kuttiyattam theatre (India), Sicilian puppet theater (Italy), Nôgaku theater (Japan), cross crafting (Lithuania), Hudhud chants of the Ifugao, cultural space of the Garifuna (Belize), the oral history of the Gelede (Benin); the second, two years later, added another 28 traditions. $^{8}$ Proclaimed masterpieces enjoyed added publicity, attention at home, and international prestige. Some received grants and contributions for them to realize their proposed action plans. According to follow-up studies by UNESCO, some of those plans to "safeguard" the traditions actually succeeded. ${ }^{9}$

In the wake of the Smithsonian conference and the masterpieces program, UNESCO, as directed by Matsuura and through the efforts of Bouchenaki and Aikawa, moved aggressively toward a new international convention in the intangible cultural heritage field. Several experts' meetings were held to refine definitions and approaches. Again, even though

President Alpha Konare of Mali, Smithsonian director Richard Kurin (U.S.), folklorist Olive Lewin (Jamaica), His Majesty Ronald Muwenda Mutebi II (Uganda), ethnomusicology professor J.H. Kwabena Nketia (Ghana), cultural director Ralph Regenvanu (Vanuatu), Her Royal Highness Basma Bint Talal (Jordan), folklore professor Dawnhee Yim (Korea), cultural official and singer Zulmar Yugar (Bolivia) singer Munojat Yulchieva (Uzbekistan).

8. An additional 43 masterpieces were selected by a reformulated jury in 2005. For a list of the jury members and proclaimed masterpieces see http://www.unesco. org/culture/ich/?pg=00103 (retrieved July 14, 2014).

9. UNESCO staff conducted several studies, following up on the impact of the masterpiece designation (UNESCO, 2003a). See also http://portal.unesco. org/culture/en/ev.php-URL_ID=32260\&URL_DO=DO_TOPIC\&URL_ SECTION=201.html (retrieved November 27, 2006). 
the U.S. was not a member of UNESCO, Smithsonian experts—cultural heritage policy director James Early and folklorist Peter Seitel attended the meeting in Turin, and the later meeting in Rio de Janeiro (Seitel, 2001b). Seitel was asked by UNESCO to draft a working definition of intangible cultural heritage for consideration by the group of international experts. Seitel successfully argued for a processual definition of intangible cultural heritage, one which relied heavily upon the agency of the cultural community in defining and practicing traditions, one focused rather on the forms or products of cultural expression that could be alienated from their creators (Early and Seitel, 2002a). Cultural workers and scholars involved at the grassroots levels in their own nations-like Ralph Regenvanu from Vanuatu and Gerald Pocius from Canada-offered strong support for such a re-centering of the definition. Community involvement and active engagement in any such state or international intervention to save a particular tradition was key. As James Early noted, "There's no folklore without the folk" (Early and Seitel, 2002b). Seitel's definition, as modified by the experts' group was later adopted by UNESCO's executive board (Aikawa, 2004).

By July 2002, UNESCO staff and a team of experts lead by Mohammed Bedjaoui, an Algerian former ambassador, minister of justice and president of the International Court of Justice, developed a preliminary draft of the convention, modeled in general upon the 1972 world heritage convention (Aikawa, 2004). That approach drew the criticism of many scholars and some of UNESCO's own senior legal staff, concerned that such a strategy undermined the difference between intangible and tangible aspects of cultural heritage and that it failed to recognize lessons learned form three decades of operation of the world heritage list. ${ }^{10}$ UNESCO called upon member states-and observer nations like the U.S. for comments. This prompted the U.S. Department of State to call together experts from various agencies to consider the preliminary draft convention and provide comments. Such meetings continued over the course of a year, and provided the guidance for U.S. delegations that would ultimately attend three meetings of intergovernmental experts in Paris at UNESCO headquarters in September 2002 and February and June 2003. It was during

10. Lyndell Prott, who served as chief of the International Standards Section in UNESCO's Division of Cultural Heritage, has on numerous occasions pointed out the poor drafting of the convention, and the unfortunate use of the 1972 world heritage convention as model (Prott, 2001). Aikawa (2004) and Bedjaoui (2004) argue that use of the 1972 convention was taken as a model because it worked, while terms and other items were appropriately modified. 
those meetings, presided over by Bedjaoui, through plenary and drafting sessions, and continual informal meetings and discussions among various delegations, that the actual language of the convention would be finalized. The U.S. was represented at these meetings by the head of its observer mission to UNESCO, State Department lawyers, Barry Bergey-the head of the National Endowment for the Arts Folk and Traditional Arts Program, and myself. Parallel to these meetings of experts, meetings of cultural ministers discussed and largely endorsed UNESCO's effort to conclude an international convention on intangible cultural heritage (Aikawa, 2004).

\section{The U.S. Develops a Position}

The immediate context for U.S. government discussion of the proposed intangible cultural heritage convention changed on September 12, 2002, when just ten days before the first intergovernmental meeting was to take place in Paris, President George Bush announced in a speech to the United Nations General Assembly in New York that the U.S. would be rejoining UNESCO. This was broadly regarded as a signal to the international community that, in light of criticism of U.S. unilateralism in international affairs-particularly with regard to Iraq, but also pertaining to issues of global environment and other policies, the U.S. administration saw the value of multilateral organizations. For many critics and skeptics, the gesture of rejoining UNESCO was a very mild, almost inconsequential signal of multilateral resolve.

At UNESCO, the announcement was warmly greeted by Matsuura who had sought U.S. re-entry into the organization. Having the U.S. in UNESCO would buttress its global spread to 190 nations, give it more power, make its programs more significant, and also enhance its budget. Given the U.N. formula for dues, the U.S. would pay $22 \%$ of the UNESCO budget-roughly $\$ 60$ million per year.

No broad or large-scale discussions took place in the U.S., either amongst the public or among various government agencies, nongovernmental organizations and other possibly concerned groups with regard to a U.S. strategy for its UNESCO membership. How did the U.S. want to proceed with UNESCO— what did it want out of its participation and involvement, how did it want to affect the organization or its own policy aims? No such guidance was articulated or broadly disseminated.

The date of U.S. re-entry into UNESCO was scheduled for October 2003, when the UNESCO General Conference would convene. Until 
that time, the U.S. would still retain its observer status. While it was not formally a member of UNESCO, it could still speak at meetings, vote in certain consultative bodies, and offer its positions-only now its positions might be taken more seriously, both by the U.S. itself as well as by fellow member states.

As the U.S. Department of State convened cultural experts and lawyers from various government departments and public agencies to discuss the proposed intangible cultural heritage convention, several underlying currents became apparent.

A major issue was the notion of a cultural treaty in itself. Cultural treaties are somewhat anathema for the U.S. For one, culture has historically not been high on the U.S. foreign policy agenda. Second, it is a domain that even domestically is not traditionally subject to a great deal of regulation. The U.S. has a generally laissez faire approach to cultural activity, leaving it mainly to the private sector and considering it largely a matter of individual choice and initiative. As in other nations, most of what might be considered the outward display of cultural expression is undertaken by people who individually or in relatively small familial or communal groups sing, dance, craft, pray, recite, cook and celebrate. Perhaps a bit more distinctively, in the U.S. there is a large non-profit public cultural sector that supports performances, concerts, museums, parades, public art work, shows and festivals. But most distinctively, the U.S. is home to huge, multinational cultural industries-the for-profit cultural sector that produces Hollywood movies, syndicated television shows, popular music, books, magazines, fast and slow foods, fashion apps, blogs and tweets- the very forms of expression associated with globalization. While the U.S. federal government helps support a number of institutions that undertake cultural work - the National Park Service, the Smithsonian Institution, the Library of Congress, the Kennedy Center, the National Endowment for the Arts and the National Endowment for the Humanities, among others, its overall contribution is relatively miniscule and generally nonnormative in character-and the same could be said for state and municipal governments as well. Unlike many other nations, the U.S. does not have a ministry of culture, nor enforceable forms of official culture-such as language or religion. Indeed, Americans generally regard culture as a matter of freedom — of association, of speech, of religion, and so on-not regulation. To be sure, Americans strongly debate cultural issues, though such typically involve the degree to which tolerance for and rights of private behavior should be recognized and accepted in the public sphere. 
Having a treaty that encouraged diverse cultural traditions in the United States seemed somewhat consistent with the work of cultural agencies. The Library of Congress American Folklife Center-which operates under the authority of the Folklife Preservation Act of 1976 and was at the time represented at meetings by its Director, Peggy Bulger, aims its efforts at preserving American folklife traditions. Bergey does the same at the National Endowment for the Arts, encouraging the recognition of exemplary cultural traditions through esteemed National Heritage Fellowships and the ongoing documentation, presentation and transmission of such traditions through a variety of programs generally dispersing funds through state agencies and NGOs. The National Endowment for the Humanities also has programs encouraging the study and documentation of local culture around the U.S. and various forms of its dissemination. The National Park Service has a large variety of programs, from those encouraging the continuity of Native American traditions, to those encouraging living heritage, oral history, grass roots and urban traditions associated with National Parks and other sites around the country. The Smithsonian too, perhaps most dramatically through the Smithsonian Folklife Festival, but also through its Smithsonian Folkways Recordings, and through various museums, has numerous programs that recognize and encourage cultural communities and traditional exemplars to practice their culture, share it with general audiences, transmit it to the next generation, and so on.

While such programs were understandable to U.S. government lawyers and officials, the necessity for an international treaty devoted to such efforts was strongly questioned. One issue was the definition of intangible cultural heritage. It seemed to be defined as a laundry list of activities without a clear sense of what might be included or not. For example, were religions intangible cultural heritage? Were whole languages? If so in the case of the former, nations might find themselves in difficult and awkward positionsseemingly intervening to preserve religious belief and practice-a problem in societies where there was separation of church and state and where there is considerable tension between religious communities If language was intangible cultural heritage, then the scope of what may be included is just about infinite. Every language on earth would have to be recognized and every one of those languages preserved and protected. Another issue was the purpose of the proposed convention-was it to simply recognize traditions by giving them international attention, was it to rescue them from becoming obsolete, was it to preserve them at all costs, or was it to 
offer them legal protection? To U.S. officials this was unclear. The scope of the proposed convention also needed clarification. Was it to help preserve especially fragile, truly endangered traditions which if discontinued would be a major loss for humankind, or was it to assure the continuity of all traditions, everywhere, even if insignificant and outmoded?

Yet another issue was the question of responsibility. Were governments truly responsible for the continuity of the traditions of their peopleparticularly in a democratic society? The U.S. might encourage cultural diversity and heritage preservation work through sundry government and public agencies, through voluntary and community groups, and through the private sector-but did it really need an international treaty to impose an obligation upon both itself and other nations? As long as such traditions were lawful, wasn't it up to individuals and communities practicing the culture to keep it alive, or not?

To government officials, it seemed like a UNESCO program that would encourage "best practices" for action plans in the area of living cultural heritage appropriate to a particular country and circumstance would do just fine-and a new international treaty was superfluous. The cultural experts tended to agree. But still, a position was needed with regard to the proposed convention.

At the most general level, the U.S. administration did not want any treaty.

Among some influential constituents, any international treaty was seen, in principle, as an intrusion upon U.S. sovereignty, and thus a non-starter. Others saw problems in international treaties that imposed obligations upon the U.S., and that the U.S. would take seriously and faithfully execute, while other signatories would ignore. Still other treaties had problems in the particular, seen as too aspirational, too easy to circumvent, or too deleterious to the U.S. if interpreted negatively. The U.S. was not in an international treaty signing mood-having repeatedly rejected the Kyoto protocol, a land-mine treaty, and the accord for the International Court of Justice. Unsaid at the time, administration officials may have even been debating the application of the Geneva conventions. Thus, the idea of signing a treaty, as perhaps innocuous and inconsequential as that on intangible cultural heritage, was still going against the grain of U.S. foreign policy.

Discussion of the proposed treaty went beyond this general orientation to the specifics. The preliminary draft of the proposed International Convention for the Safeguarding of the Intangible Cultural Heritage was very 
poorly written and had numerous particular problems. The writing was cleaned up through subsequent drafts. There were also aspects of the proposed convention that could be lauded.

Rather than reporting on discussions that took place over the course of a year and involved various drafts, proposals and revisions as they emerged through the intergovernmental meetings of experts, let me try to summarize the consensus, areas of contention and debate over key provisions of the proposed convention.

On the seemingly positive side, the proposed convention pointed to the importance of respect and tolerance for cultural diversity within nations and across the globe. Importantly, intangible cultural heritage was defined, by the proposed convention as, for international purposes, consistent with human rights—so no one would be in a position of having to respect such odious cultural traditions as slavery, genocide, human trafficking or female infanticide. The recognition, respect and tolerance for cultural diversity was both a moral/legal and historical cornerstone of the American experience, and one, the consensus would have it, which the U.S. should endorse and encourage. The proposed treaty also envisioned a fairly bottom-up, participatory/grassroots and democratic process of community involvement and consultation in the development of plans to recognize and safeguard intangible cultural heritage. National governments could not just go off and do want they wanted with regard to local cultural traditions, but had to fully and equitably engage the people and communities whose traditions are to be safeguarded (cf. Article 15). This was broadly recognized as something quite consistent with American proclivities, and as a vast improvement to the more usual top-down government and bureaucracy-driven cultural programs practiced throughout most of the world. ${ }^{11}$

Also, there was a consensus that American institutions had much to contribute to the practice of researching, documenting, recognizing, exhibiting, disseminating, and preserving intangible cultural heritage encouraged, but not required by the convention. A number of American organizations worked in the U.S. and in concert with partners around the world in such activities; they had gained much experience and professional knowledge, and were widely regarded as leaders in the field. Signing onto the convention would help continue that contribution to a worthy endeavor. Furthermore, American organizations had a range of experiences in integrating cultural heritage work with economic development, civic and

11. Consideration of these points at the time were mirrored in treatments emerging scholarly and academic circles; see Lenzerini (2011) and Blake (2008). 
educational efforts that could benefit local communities. The convention could be a conduit for communicating those experiences to organizations in other nations so that cultural efforts-so often disjointed from other socioeconomic initiatives-could possibly help in the arenas of health care, poverty reduction, and democracy building.

While all the above were noble possibilities, the proposed convention really only required that nations meet their legal obligation to develop inventories of their intangible cultural heritage. Given that inventories meant more than one, singular, unitary list, officials, lawyers and cultural leaders were convinced that U.S. federal and state agencies were already doing what the convention would require. ${ }^{12}$ The U.S. would not need to undertake a new inventorying project if it accepted the treaty, but rather rely on the present work of the Library of Congress, the Smithsonian, the National Park Service, the National Endowment for the Arts and the National Endowment for the Humanities.

On the negative side, there was consensus that the treaty, as proposed, would probably not succeed in doing what it aimed to do. It could merely create great bureaucracies of list makers, staffers from government ministries who would assemble volumes of superficial reports about various traditions, store them in government buildings, and do little to actually help communities and empower cultural practitioners. Indeed, some worried that it could do the reverse, excluding various traditions and communities from social recognition, "freezing" traditional practices in place, and disempowering cultural practitioners vis-à-vis bureaucrats. ${ }^{13}$

12. Discussion in the meetings of experts revealed sharp differences on the matter of list making. Generally, European and western representatives, and those in the cultural fields objected to the making of inventories as a neo-colonial exercise reminiscent of $19^{\text {th }}$ century gazetteers and compendiums of customs and as a diversion from the real work of cultural preservation (see Kirshenblatt-Gimbett, 2004; Kurin, 2004). Representatives mainly from Africa, South America, Asia and the Pacific Islands, and those with more managerial and diplomatic backgrounds thought inventories were a key to rational management of cultural resources and an absolutely necessary aim of the convention. Rather than insist on one singular inventory for each nation, a compromise of the two positions in the convention thus allowed for each nation to have inventories of intangible cultural heritage. By having multiple lists and not necessarily comprehensive ones, those nations which did not want to engage in a national inventory project could get by on extant lists, while those which did want to develop a singular inventory could do so. Barry Bergey played a key role in a drafting committee in encouraging the plurality of inventories allowed in the convention.

13. See Arizpe (2004), Kirshenblatt-Gimblett (2004), Haftstein (2008), Brown 
Some cultural experts raised questions with regard to Native American cultural issues. The treaty might prompt intrusions into Native American life-what if people did not want their traditions documented; what if they did not want to share their intangible cultural heritage with outsiders, or even have it recognized for fear of exploitation or expropriation? More so, could the treaty, in recognizing "cultural communities" inadvertently affect the legal definition of groups and particularly Native Americans in the U.S? Native Americans have a particular status in U.S. law, as nations. The proposed treaty did not distinguish recognized indigenous populations from others and in recognizing the need for community participation and involvement might have unintended consequences for how those communities—particularly native ones, are defined.

Other articles and provisions of the proposed treaty provoked opposition on technical grounds. A key sentence (Article 11b) stated that each states party shall "take the necessary measures to ensure the safeguarding of the intangible cultural heritage present in its territory." The term "necessary" seemed much too broad and foreboding. Might that mean that governments could force the sons of musicians and daughters of weavers to take up their parents' occupations even if they wanted to be doctors or lawyers instead? The U.S. tried, but failed, to get the wording changed to "appropriate" instead. And having governments "ensure" results seemed quite unrealistic when it comes to the preservation of numerous traditions. It is impossible to guarantee an outcome given the contingencies and the difficulties in predicting what cultural traditions live and die. Ensuring outcomes could lead to a level of government involvement and control over citizen interactions that would be untenable and inconsistent with other civil rights both in the United States and in other nations.

Most of the government concern about the proposed treaty on intangible cultural heritage revolved around its potential impact upon intellectual property rights. There had been strong analyses of the implications of the 1989 recommendation for property rights (Simon 2001, Prott 2001). There was debate at UNESCO during the drafting period over whether or not the treaty should have provisions affecting the ownership of cultural traditions. Could nations claim stewardship, guardianship or outright ownership of traditional intangible cultural heritage? In this way, inventories would be the first step in asserting intellectual property rights over such intangibles.

This was a contentious matter within UNESCO and among member

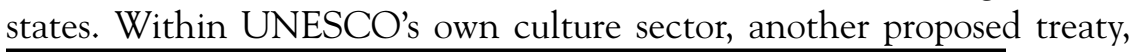
(2005), and Kreps (2008). 
one shorthandedly called "cultural diversity," and later to be named the Convention on the Diversity of Cultural Contents and Artist Expressions, was making its way through the organization. Informed gossip at the Paris intergovernmental meetings had it that the French government was pressuring UNESCO to move quickly on the intangible cultural heritage convention so as to make way for this, more consequential treaty. The proposed cultural diversity treaty, a brainchild of Canadian heritage minister Sheila Copps and the International Network for Cultural Diversity, was not so much about the ethnic diversity of the world's people or national populations, as it was about the competition and support for nations in their commercial cultural industries-film, media, publications, and mass marketed products. That proposed treaty was perceived by supporters as a corrective to World Trade Organization rules which were biased in favor of U.S.-based cultural industries. The proposed treaty asserted the rights of governments to encourage the production of homegrown cultural products and restrict cultural imports from other nations, and claim what seemed like national intellectual property rights over cultural goods and services (Kurin, 2005). Debate over such rights was further complicated by the fact that another multilateral organization, the World Intellectual Property Organization (WIPO), was in a multi-year discussion about the status of traditional knowledge and intellectual property rights that might pertain to intangible cultural heritage (Wendland, 2004; WIPO, 2006a; 2006b).

Given those circumstances, member states came to an agreement in the debate over provisions of the intangible cultural heritage convention that the discussion of intellectual property rights should be postponed to the cultural diversity treaty debate. Hence, the International Convention for the Safeguarding of Intangible Cultural Heritage has what is known as a "savings clause," explicitly stating that it would have no effect upon intellectual property rights or any other international instrument regulating those rights (cf. Article 3). Despite that, the U.S. Patent and Trademark Office (PTO) was most concerned that the intangible cultural heritage convention could provide a slippery slope in recognizing the intellectual property rights of national governments with regard to traditional cultural material. Specifically, the PTO argued, days before the vote on the convention, that the treaty had as one of its aims ensuring the mutual respect of diverse cultures. A PTO lawyer argued that "respect" had been used as a vehicle for asserting new intellectual property rights in the discussion of the Convention on Biological Diversity. "Respect" was interpretable as granting an internationally sanctioned privilege to the holders or practitioners of a 
culture as somehow having rights over their "possession" of their cultural traditions. If the U.S. agreed that it respected other cultures, it could be interpreted as recognizing the claim of those cultural practitioners to have intellectual property rights over their traditional cultural expressions. If legally obligated to respect another culture, a big corporation might not be able to turn someone else's sacred mantras into jingles to sell potato chips; Volkswagen, for example, might be forbidden to name its new automobile after a North African ethnic group-the Taureg. That is, the respect provision could implicitly limit the rights of some to exploit someone else's traditional cultural expressions-a practice that under current law is fair game.

I wrote the original position paper for the U.S. Department of State, recommending that the International Convention for the Safeguarding of Intangible Cultural Heritage, at that time in conference draft, be slightly amended and supported by the United States. Such a position was vetted through and supported by professionals involved in cultural work at the Smithsonian, the Library of Congress, the National Endowment for the Arts, the National Endowment for the Humanities, the Bureau of Land Management, and the National Park Service. The convention, with amendments, was viewed as acceptable on the technical merits and as consistent with cultural democracy and action-oriented, researchbased participatory, grassroots preservation efforts-orientations that characterized their own best cultural preservation practices. U.S. support for the convention would also demonstrate good global citizenship, indicating that as the U.S. re-entered UNESCO it would stand together with other nations on matters of universal concern and appeal. While still regarding the treaty as flawed and lacking any enthusiasm for it, the involved State Department professionals nonetheless accepted the position statement.

\section{America Re-Enters UNESCO}

First Lady Laura Bush led a distinguished delegation to Paris to mark the U.S. re-entry and reiterate its commitment to UNESCO's purposes. In her speech to the General Conference on September 29, 2003, she found common ground between a number of U.S. government priorities and UNESCO programs, certainly in the area of literacy, education, and HIV/ AIDS prevention. She also used the term "respect" twelve times, in a nontechnical way, arguing that respect and tolerance for difference was good and important to achieve peace and fight terrorism in a post-9/11 world. ${ }^{14}$

14. See Bush (2003). 
A few weeks later, when it came time to vote on the convention, the U.S. delegate abstained.

I was told that it was not so much PTO opposition or lack of enthusiasm for the treaty that prompted the vote as it was a matter of registering concern for good governance at UNESCO.

The U.S., in returning to UNESCO, had publicly proclaimed that the organization had corrected its weaknesses-among them a large, inefficient bureaucracy and an anti-U.S. bias. Yet, despite rationalization efforts by Director General Matsuura and his principal deputies, the organization still had a strong bureaucracy and somewhat opaque operational features including a system of chairmanships with "consensual" decision making for its meetings. Lacking anything like the United Nations Security Council, the U.S. delegation had found that it was becoming just another one of 190 members - despite the fact that it pays the highest dues by far of any member. It is not granted "superpower status" in terms of consultations and privilege and given its long absence, found itself relativized and even ignored by other member states content to do without it. UNESCO has long been dominated by regional alliances of countries and representatives not necessarily sharing U.S. interests. While it was diplomatically welcomed back to UNESCO, the U.S.'s own concerns did not go to the head of the queue-especially at a time when it was so widely perceived as rejecting multilateralism in international affairs. General U.S. desires for solid policy formulation, clarity of purpose, explicit procedures, fairness, accountability and the like in UNESCO, were frustrated in the process of arriving at the intangible cultural heritage convention, and provoked a response. The U.S. wanted UNESCO to know that it regarded international conventions-such as the more consequential one on "cultural diversity" as serious measures; that it wanted healthy, serious, engaged dialog and consultation. It did not want UNESCO to impose false consensus, generate politically symbolic, practically meaningless ideological instruments, and ramrod through treaties. The U.S. thus abstained to deliver that message. Whether this particular convention was the case to register that displeasure, and whether the message was heard or not, and what consequence it may have for future treaties, is another matter.

\section{Subsequent Developments}

Even if the UNESCO delegation had supported the intangible cultural heritage convention, it is doubtful that it would have won ratification in 
the U.S. Senate. At the time, President Bush's request to pay the dues for re-entering UNESCO was stymied by Senate action. This was eventually resolved, but lack of knowledge of UNESCO and its programs, and suspicion of multilateral organizations would have made it exceedingly difficult to win support of a new convention thought to be somewhat unnecessary for the U.S.

UNESCO took up the cause of promulgating the convention and working with member states on ratification. Algeria became the first to accept the treaty - a choice and decision probably linked to Bedjaoui's role both in the government and as chair of the intergovernmental meetings to draft the convention. Other nations followed suit. Various regional forums met to discuss and endorse the convention. UNESCO published a special double volume of Museum International (2004) with articles about the convention. The International Council of Museums made intangible cultural heritage the theme of their triennial meeting in Seoul in 2004, and devoted keynote addresses and numerous sessions to its discussion (ICOM, 2004).

On the U.S. side, the President appointed an Ambassador, Louise Oliver, to UNESCO. Consistent with legislation, the U.S. National Commission for UNESCO was appointed by Secretary of State Colin Powell. At its 2005 meeting, its committee on culture recommended that the Department of State consider supporting the intangible cultural heritage convention. The commission adopted the recommendation, but no follow-up action was taken. In its meeting the next year, the commission asked the Department of State to again re-examine the U.S. position with regard to the convention.

In 2006, parties to the UNESCO convention met to elect those member states whose representatives-presumably experts in the field-would serve on an intergovernmental committee that would recommend the ways in which the treaty would be operationalized. The work of that committee would be crucial in interpreting the convention, giving guidance to nations, and managing the international aspects of the treaty. That international work would consist of two lists of intangible cultural heritage-a "representative" list of recognized traditions and an "endangered" list, as well as an international fund to be used for safeguarding selected traditions.

To administer the treaty's operations, UNESCO ramped up staffing for an intangible cultural heritage unit under the leadership of Rieks Smeets, a linguist from the Netherlands, who took on the role following Aikawa's 
retirement. UNESCO sought a strong and knowledgeable program assistant, and I recommended to Bouchenaki the Smithsonian's Frank Proschan, a folklorist with a $\mathrm{PhD}$ from the University of Texas who had worked the Smithsonian Folklife Festival for decades, done intensive work in Vietnam, and was conversant with and experienced in international issues involving cultural heritage. Proschan had among his mentors some of the leading lights of the American public folklore movement-Ralph Rinzler, Bess Hawes, Archie Green and Richard Bauman. He was hired by Smeets in the autumn, 2006 in time for the meeting of the intergovernmental committee of experts in November.

The committee met in Algiers-again because of Bedjaoui's role and their position as the first nation to ratify the convention. The committee concentrated its work on the lists and the criteria by which items recommended by nations would be so inscribed. By concentrating on the international prestige aspects of the treaty, the committee seemed to be replicating the work of the UNESCO masterpieces program-whose list it absorbed as a result of the treaty coming into effect. The committee seemed to have had little time for other matters of greater impact such as considering the involvement and participation of community members and tradition bearers in the process of safeguarding, or connecting the list making to other areas of social, economic and educational concerns. ${ }^{15}$

Following closely on the heels of the first meeting of the intergovernmental committee, the U.S. Department of State convened a meeting of experts from government and public agencies to reconsider the convention in light of the U.S. National Commission for UNESCO recommendation. Positions similar to those in the initial debate emerged. The cultural agency representatives felt that while the convention had its flaws, it had positive aspects that could contribute to good cultural work around the globe. U.S. participation in the convention, through its general assembly, and in the future, through its committee and other convocations of experts, could help in the realization of the convention's more aspirational purposes. Representatives from the PTO and the U.S. Trade Representative had concerns about either the inadvertent or intentional misuse of the convention for intellectual property rights claims by nations. Other officials saw the advantages of supporting the convention for purposes of public diplomacy. Ratifying the convention would reinforce U.S. promotion of cultural tolerance and respect, grassroots democracy,

15. Invited to the meeting, I could not attend. However I did voice these concerns in a letter to the intergovernmental committee. 
and related values. It would demonstrate solidarity with rather than isolation from other nations. It would also enable the U.S. to distinguish its position-for cultural diversity and safeguarding of cultural traditions as a civic matter-from its deep-seated opposition to the 2005 convention on the diversity of cultural expressions as a means of economic protectionism and state control of culture. Most telling, support for the convention was not rejected out of hand, and proceeded to higher levels in the administration. There, lacking an impending and compelling reason for action and given a panoply of other higher priority interests and concerns, it sat.

Meanwhile, at UNESCO Smeets, Proschan and others sought to operationalize the convention, develop workshops and materials to guide nations in developing national inventories and lists, attend numerous meetings, disseminate print materials and flesh out a website to promulgate information about intangible cultural heritage. At the same time, even absent the convention the Smithsonian was working with UNESCO on two initiatives - one, having the Smithsonian take over the production and distribution of UNESCO's Collection of Traditional Music recordings series, and two, examining the possibility of featuring the work of the convention through community case studies at a future Smithsonian Folklife Festival on the National Mall in Washington, D.C. The former finally came to fruition years later; the latter has not. In 2008, Smeets retired and was replaced by Cécile Develle, a French anthropologist who had worked closely with Matsuura at UNESCO.

The intergovernmental committee and assembly had additional meetings. Chérif Khaznadar, a poet and cultural polymath born in Syria but headquartered in France as the founder and Director of the Maison des Cultures du Monde became chair of the convention's assembly in 2008. He offered doses of realism with regard to the convention, its operations and ultimate efficacy. At the Abu Dhabi meeting of 2009 he noted that the convention was troubled and needed attention. It had been successful in bringing attention to traditional heritage but had been slow and laborious in developing its action plan. Yet, despite the drawback, the need to do something was compelling. Recognizing that he could, sadly, make a his own very long list of traditions that had been lost over the course of his own career, he held that the convention represented a benchmark from which there was no turning back if those important cultural expressions were going to be preserved for the future. ${ }^{16}$

With more and more nations acceding to the convention, UNESCO

16. See Khaznadar (2009). 
held more meetings of the signatory parties, forming them-as is common practice - into areas or regions of the world. Procedures were more finely operationalized for nominating and selecting various intangible cultural heritage expressions for recognition on the representative and endangered or urgent safeguarding lists. UNESCO started to accredit non-profit, scholarly and cultural organizations to serve as advisors to the conventionthese now number more than 170_-half of which are from Belgium, France, India and Italy, but include several from the United States, including the American Folklore Society and the Center for Traditional Music and Dance. UNESCO began to solicit countries to establish regional centers focused on the work of the convention-with those now gearing up in Algeria, Brazil, Bulgaria, China, Iran, Japan, Peru and Korea. UNESCO produced various booklets, websites, and kits to guide nations through the process of list making and documentation, using the experience of several of the signatories as exemplars. ${ }^{17}$

Some of the work of UNESCO seemed formulaic and bureaucraticoften a feature of governmental systems magnified in an intergovernmental context. Other tasks-like having a competition to find an emblem or logo for the convention-seemed somewhat pedestrian if necessary. Although ways of speaking, writing and otherwise representing intangible cultural heritage became increasingly nuanced and sophisticated in light of professional and scholarly examination, the convention took some public blows for items on its list, like the gastronomic meal of the French and the Mediterranean diet. Nonetheless, the making of inventories, highly suspect among American and other critical anthropologists, was noted by UNESCO as not an "abstract" activity but an "instrumental" one, whose end was the safeguarding of cultural traditions. Similarly, the UNESCO intangible cultural heritage unit grew increasingly comfortable with encouraging community involvement and participation in the goals of the convention, providing case studies of best practices, and explicitly distancing itself from the idea of "freezing" living culture in the manner of how its sister world heritage convention preserved sites on its list.

All of these concrete developments brought the operationalized convention closer to what many American cultural workers and officials saw as appropriate and sound practice. That had little impact though in a reconsideration of the convention by the U.S. government. Instead, that came about as a result of the U.S. election in 2008 and President Barack Obama's appointment of David Killion as Ambassador to UNESCO in

17. See UNESCO Intangible Cultural Heritage website. 
mid-2009. Killion had worked in Congress as an aid to Representative Tom Lantos, a strong supporter of UNESCO, and member of the delegation including Laura Bush when the U.S. re-joined the organization. I briefed Killion on the convention and the fact that for several years, members of the U.S. Commission for UNESCO_Joe Wilson, Jonathan Katz, Murray Horwitz, Sandra Gibson and I, with support from Frank Hodsell, had recommended the U.S government re-examine our position.

On January 27, 2010, a sub-Interagency Policy Committee met to consider U.S. engagement with UNESCO for the National Security Council. UNESCO was at least on the radar for the new administration and its State Department. A few weeks later, I met with U.S. UNESCO mission staff in Paris in meetings occasioned by the earthquake in Haiti. Talk about endangered culture and traditions! The Smithsonian participated in sessions with UNESCO on how to respond to issues of cultural sites, collections and traditions damaged by the earthquake and in need of aid in its aftermath. The Smithsonian put together a large-scale effort with the Haitian government and other cultural organizations, U.S. cultural agencies including the President's Committee on the Arts and the Humanities, the Institute of Museum and Library Services, the National Endowment for the Arts and the National Endowment for the Humanities, American nongovernmental organizations, ICCROM, UNESCO and others to take over and equip a U.N. building in Port-au-Prince, hire Haitian staff, send more than 100 conservators to Haiti, train 150 Haitians in conservation and collection management, and save more than 35,000 paintings, sculpture, murals, historical artifacts, rare books, and archival documents. On the intangible side, the Smithsonian worked with various craft cooperatives, buying items and bringing musicians and craftsmen to its annual summer Folklife Festival. ${ }^{18}$

With heightened attention to culture and cooperation with UNESCO and its leadership in the persons of Director General Irina Bokova, who also assumed office in 2009, and Killion, Robert Mearkle, a policy advisor in the Office of UNESCO Affairs at the U.S. State Department took the lead in exploring the idea of the U.S. accepting and ratifying the intangible cultural heritage convention. Such a re-examination began in February 2010 with the UNESCO office and the Office of the Legal Advisor at the Department of State. We collected documentation of the previous deliberations, briefings and reports. Mearkle composed a briefing paper summarizing the issues-once again noting questions about the savings

18. See Kurin (2011). 
clause, the task of composing inventories, access to heritage, whether or not the U.S. was already in compliance, reporting requirements, possible recognition of cultural property, and consistency with federal and state laws. He also raised some new concerns - since many of the endangered traditions would be in the South, did that imply an obligation on countries of the North-such as the U.S. to support them? Also, he noted that the convention could be politicized where a tradition overlapped the borders of two countries. Such might be practiced by a minority or marginalized community and one country might want to declare the tradition endangered over the objection and indeed as a result of the persecution of its neighbor.

The State Department involved the various U.S. cultural agencies once again-its own subdivisions as well as the National Endowment for the Arts, the National Endowment for the Humanities, the National Park Service, the Advisory Council on Historic Preservation and Smithsonian, the Patent and Trade Office, the U.S. Copyright Office, the Library of Congress and the Institute for Museum and Library Services. It formed two working groups, one to address legal and legislative matters, the other to deal with policy matters. Working papers were developed and the State Department formed another group to deal with legal issues flagged by the groups.

By April 2011, more than a year after the review began, issues for some U.S. agencies remained. The "necessary measures" clause was still a cause of some consternation. Questions about implementing legislation needed in the U.S. remained. Implications for Native American and Native Hawaiian traditions as defined under U.S. law were not settled. And the question of where and how to get the additional funds $-\$ 800,000$ in annual assessments, which though relatively miniscule in government terms, lingered. By May, Duvelle and Proschan had agreed to teleconference with key U.S. officials to answer questions about the convention, and the State Department was planning for Hillary Clinton to visit UNESCO and become the first sitting U.S. Secretary of State to do so since its founding in 1945.

Clinton visited UNESCO on May 26, lauded UNESCO's work, Bokova's fresh leadership and helped launch the Global Partnership for Girls' and Women's Education. She recognized Laura Bush's support of UNESCO and reaffirmed her own with regard to education. She clearly noted the importance of UNESCO's cultural preservation work-particularly the world heritage list, and tied it to her own efforts as First Lady in initiating the Save America's Treasures program in the United States. ${ }^{19}$ While that 19. See Clinton (2011). 
program was primarily aimed at tangible cultural sites and collections, it did include intangible heritage. In her speech, Secretary Clinton did not mention the intangible cultural heritage convention-which would have been premature at the time.

State Department reconsideration of the convention hit a snag barely a month later in July 2011 when Mearkle's term at the UNESCO office ended. The teleconference with UNESCO was cancelled. While the informal review had indicated a general consensus to proceed, progress toward a formal "Circular 175" review-so named after the State Department guideline for recommending treaty acceptance stalled.

While the effort could have again picked up steam in the autumn, another, more serious and pressing matter for the U.S. government was making its way toward the UNESCO general assembly. The Palestinians, who had observer status were seeking full membership in UNESCO as a Palestinian state and were likely to get it. By October 2011 UNESCO's executive council voted to admit Palestine over U.S. objections; the full general assembly backed this with a 107 to 14 vote with 52 abstentions by month's end. Provisions of U.S. law passed decades earlier disallowed the government from paying its dues to any U.N. organization admitting the Palestinians as a member, and the Obama administration saw no way of reversing this in Congress.

Despite repeated statements that the U.S. is committed to and supports the UNESCO mission, the U.S. has not paid its annual dues of about $\$ 60$ $\$ 70$ million. This created an immediate budgetary crisis for UNESCO, which despite receiving some additional funds from other nations, had to make deep cuts in staff, program and support. Two years later, UNESCO has still not made up for the budget loss of its highest dues-paying member. And, in accord with UNESCO rules, after not paying dues for two years, the U.S. has now lost its formal vote in UNESCO matters. Despite this, the U.S. government continues to voice support for the organization and participate in a wide variety of its programs. In mid-2014 the U.S. succeeded in having one of its nominated sites added to the world heritage list.

\section{Conclusion}

The U.S. government debate over the intangible cultural heritage convention was, and still is, enmeshed with a number of issues that range from its own understanding of the relationship between government and the regulation of culture to the specifics of the treaty, from the political 
and economic context of multilateral regulation to the crisis of UNESCO membership and dues paying spawned by the admission of Palestine. Indeed it is nigh impossible to image serious reconsideration of the convention until after this latter issue is resolved.

If it is, attention can be refocused on the convention. In the broadest sense, the treaty's text is a statement of values-reinforcing the idea that the practice of one's culture is a human right (Lenzerini, 2011). It recognizes that all cultures give purpose and meaning to lives and thus deserve to be tolerated to the extent they do not violate human rights. The document encourages governments to respect the varied cultural traditions practiced by people within its jurisdiction. In this sense, as an aspirational statement usually taking the form of a non-binding international declaration, it would likely be appealing to any U.S. government.

However, as a "hard" normative instrument which seeks to impose legal obligations upon its signatories, it is problematic, and paradoxically so. From a U.S. point of view, it seeks to regulate a domain of behaviorculture, not usually the subject of government law making. While other nations may see culture as the legitimate domain of explicit government policy and decision making, in the U.S. this is not the case. Where it is, particularly in international law, the U.S. has tended to support treaties of a very specific nature, with bounded scope, purpose and intent, thought to be necessary rather than discretionary in terms of U.S. and world interests. Simply put, the current convention is too diffuse and lacks the precision and compulsion needed to fully justify legal regulation to government officialdom. Facing U.S. senators stingy about ratifying international laws, and even Supreme Court justices questioning their application, it will be difficult for any U.S. President to argue that this particular convention is both legally necessary and justified. The same might be said for the longlived world heritage convention were it to come up for consideration today.

An alternative argument, that supporting the convention is a means of the U.S. achieving or showing off international leadership and prestige-as was the case with the world heritage convention back in the late 1960s and early 1970s, would also be ineffective. That kind of leadership in today's multipolar world is simply not as important as it was during the Cold War era. Besides, the treaty is already in force in more than 160 nations-so the U.S. would be seen as following, not leading universal acceptance.

From the standpoint of the foreign policy of both the recent Bush and current Obama administrations, the convention stands at the fulcrum of 
two interests. Domestically, a very strong constituency is absolutely opposed to treaty-signing, seeing in it the abdication of U.S. sovereignty over its own affairs. Indeed, during Bush's term, the U.S. National Commission for UNESCO, in assessing the organization's priorities, recommendedwith some limited opposition - that UNESCO should not be developing international treaties as part of its mission. Counterbalancing this tendency has been the political interests of both the Bush and Obama administrations in realizing more effective public diplomacy and being seen less as a unilateral actor and more as a builder and leader of multilateral coalitions and consensus. Increased attention to and participation in multilateral forums-the very reason for the U.S.'s re-entry into UNESCO-is one way of demonstrating this.

U.S. demonstration of being a good, cooperative team player in the cultural arena seems like an easy win, especially given the much tougher political and economic sectors. The U.S. is sometimes portrayed and seen as inadequately displaying its concern for and appreciation of other nations' traditions, religions, languages and cultural products, and has suffered in public opinion around the world as a result. That is somewhat anathema to the fact that the United States has often, though of course not always, been a welcoming home for the diversity of the world's peoples and cultures. Acquiescence to the intangible cultural heritage convention would seem to be a convenient way to join a multilateral effort and also show respect to the world's diverse cultures without what anybody could argue was a loss of sovereignty or imposition of great cost or responsibility.

While some U.S. trade officials are worried that the convention may help nations claim new intellectual property rights over their intangible cultural heritage and then use those claims to their advantage in bilateral and multilateral trade agreements, such concerns seem misplaced. The intangible cultural heritage treaty specifically avoids such declarations of new property rights, and the worry is more appropriately voiced with regard to the 2005 Convention on the Protection and Promotion of the Diversity of Cultural Expressions. That treaty, which also has gone into effect with strong U.S. disagreement, does have consequences for government rights over cultural goods and services-tangible and intangible, has no "savings" clause, and thus seeks to directly affect trade agreements negotiated bilaterally and under WTO auspices. But since that treaty is already operating with firm U.S. opposition, the battleground has shifted, and there is no reason for the U.S. to oppose the intangible cultural heritage convention on commercial grounds. 
Assuming the U.S. can work through the legal and regulatory, political and economic issues surrounding support for and hesitation about the intangible cultural heritage convention, cultural officials and professionals need to focus on the likelihood of actually achieving the cultural ends envisioned. On the positive side, the U.S. should be satisfied with much of the strategic approach embodied in the convention. It privileges culture practitioners and communities vis-à-vis the state. It encourages safeguarding activities to be integrated with legal, educational, and economic development efforts where appropriate so that cultures may retain their vitality and dynamism. In short, it provides for a more democratic, participatory and practical approach than any UNESCO treaty to date, and could indeed actually help safeguard cultural traditions worldwide. On the down side, the convention could lapse into a mere program of bureaucratic list-and international prestige-making that will, only marginally-and perhaps even negatively, affect cultural traditions. The programs developed through the convention could be weighted down by the infamous UNESCO bureaucracy and a complacent, self-referential institutional machinery. So far, though, UNESCO and convention leaders seem to be trying to steer away from these shoals. While one would hope those programs would be purposeful and imaginative enough to generate the substantial private sector financial support that will be needed to make them successful, there is no guarantee that will happen. Given that the convention, while flawed, can be the basis of good cultural work around the globe, U.S. support for it and involvement with its programs could be a very helpful factor. If the U.S. ratifies the treaty the considerable knowledge and experience gained by thousands of cultural workers and its public agencies at national, state and local levels over the course of decades can be brought to bear in the development of programs to help safeguard cultural traditions. If it doesn't, it will be much more difficult for that knowledge and experience to suffuse international cultural practice, and the loss will be felt in communities around the globe. 


\section{References}

Aikawa, Noriko, 2001, "The 1989 Recommendation on the Safeguarding of Traditional Culture and Folklore: Actions Taken by UNESCO for Its Implementation." In Peter Seitel (ed.), Safeguarding Traditional Cultures: A Global Assessment: 13-19. Washington: Smithsonian Center for Folklife and Cultural Heritage and UNESCO.

Aikawa, Noriko, 2004, "An Historic Overview of the Preparation of the UNESCO International Convention for the Safeguarding of the Intangible Cultural Heritage." Museum International 221/222: 137-149. Aikawa, Noriko, 2008, "From the Proclamation of Masterpieces to the Convention for the Safeguarding of Intangible Cultural Heritage." In Laurajane Smith and Natsuko Akagawa (eds.), Intangible Heritage: 13-44. New York: Routledge.

Arizpe, Lourdes, 2004, "Intangible Cultural Heritage, Diversity and Coherence." Museum International 56(1-2): 130-136.

Bedjaoui, Mohammed, 2004, "The Convention for the Safeguarding of the Intangible Cultural Heritage: The Legal Framework and Universally Recognized Principles.” Museum International 221/222: 150-155.

Blake, Janet, 2008, "UNESCO's 2003 Convention on Intangible

Cultural Heritage: The Implications of Community Involvement in Safeguarding." In Laurajane Smith and Natsuko Akagawa (eds.), Intangible Heritage: 45-73. New York: Routledge.

Bouchenaki, Mounir, 2001, "Opening Address." In Peter Seitel (ed.), Safeguarding Traditional Cultures: A Global Assessment: 5-7. Washington: Smithsonian Center for Folklife and Cultural Heritage and UNESCO. Brown, Michael, 2005, "Heritage Trouble: Recent Work on the Protection of Intangible Cultural Property." International Journal of Cultural Property 12(1): 40-61.

Bush, Laura, 2003, "Remarks to UNESCO Plenary Session in Paris." September 29, 2003. http://georgewbush-whitehouse.archives.gov/ news/releases/2003/09/20030929-6.html (retrieved July 6, 2014).

Clinton, Hillary, 2001, "Speech to UNESCO for the the launch of UNESCO's Global Partnership for Girls' and Women's Education." May 26, 2011. http://unesco.usmission.gov/partnership-girls-womeneducation.html (retrieved July 6, 2014).

Early, James and Peter Seitel, 2002a, "UNESCO Meeting in Rio, Steps toward a Convention." Smithsonian Talk Story 20: 13.

Early, James and Peter Seitel, 2002b, "No Folklore without the Folk."

Smithsonian Talk Story 21: 19-21.

Graves, James Bau, 2005, Cultural Democracy: The Arts, Community, and 
the Public Purpose. Champaign: University of Illinois Press. Hafstein, Valdimar, 2008, "Intangible Heritage as a List: From Masterpieces to Representation." In Laurajane Smith and Natsuko Akagawa (eds.), Intangible Heritage: 93-111. New York: Routledge.

ICOM (International Council of Museums), 2004, "Seoul 2004." ICOM News 57(4), Special Issue: 3.

Khaznadar, Chérif, 2009, “Address.” Abu Dhabi, September 28, 2009. www. unesco.org/culture/ich/doc/src/02264-EN.doc (retrieved July 6, 2014). Kirshenblatt-Gimblett, Barbara, 2004, "Intangible Heritage as Metacultural Production." Museum International 221/222: 52-64.

Kreps, Christina, 2008, "Indigenous Curation, Museums, and Intangible Cultural Heritage.” In Laurajane Smith and Natsuko Akagawa (eds.), Intangible Heritage: 193-208. New York: Routledge.

Kurin, Richard, 1998, Smithsonian Folklife Festival: Culture of, by and for the People. Washington: Smithsonian Institution.

Kurin, Richard, 2001, "The UNESCO Questionnaire on the Application of the 1989 Recommendation on the Safeguarding of Traditional Culture and Folklore: Preliminary Results." In Peter Seitel (ed.), Safeguarding Traditional Cultures: A Global Assessment: 20-35. Washington: Smithsonian Center for Folklife and Cultural Heritage and UNESCO. Kurin, Richard, 2003, "UNESCO Votes New Intangible Cultural Heritage Convention." Anthropology News 44(9): 22.

Kurin, Richard, 2004, "Safeguarding Intangible Cultural Heritage in the 2003 UNESCO Convention: A Critical Appraisal." Museum International 221/222: 66-76.

Kurin, Richard, 2005, "Regulating Culture." Anthropology News 46( 9): 28. Kurin, Richard, 2011, Saving Haiti's Heritage: Cultural Recovery After the Earthquake. Washington: Smithsonian Institution.

Lenzerini, Frederico, 2011, "Intangible Cultural Heritage: The Living Culture of Peoples." European Journal of International Law 22(1): 101 120.

Matsuura, Koïchiro, 2004, "Preface." Museum International 221/222: 4-5. Mayor, Federico, 2001, "Message." In Peter Seitel (ed.), Safeguarding Traditional Cultures: A Global Assessment: 5-6. Washington: Smithsonian Center for Folklife and Cultural Heritage and UNESCO.

McCann, Anthony et al., 2001, "The 1989 Recommendation Ten Years On: Towards a Critical Analysis.” In Peter Seitel (ed.), Safeguarding Traditional Cultures: A Global Assessment: 36-41. Washington: Smithsonian Center for Folklife and Cultural Heritage and UNESCO. Nas, Peter, 2002, "Masterpiece of Oral and Intangible Culture: Reflections 
on the UNESCO World Heritage List." Cultural Anthropology 43(1): 139-148.

Prott, Lyndel, 2001, "Some Considerations on the Protection of the Intangible Heritage: Claims and Remedies." In Peter Seitel (ed.), Safeguarding Traditional Cultures: A Global Assessment: 104-110. Washington: Smithsonian Center for Folklife and Cultural Heritage and UNESCO.

Seeger, Anthony, 2001, "Summary Report on the Regional Seminars." In Peter Seitel (ed.), Safeguarding Traditional Cultures: A Global Assessment: 36-41. Washington: Smithsonian Center for Folklife and Cultural Heritage and UNESCO.

Seeger, Anthony, 2004, "Traditional Music Ownership in a Commodified World.” In Simon Frith and Lee Marshall (eds.), Music and Copyright, 2nd edition: 157-171. Edinburgh: Edinburgh University Press.

Seeger, Anthony, 2008, "Lessons Learned from the ICTM (NGO) Evaluation of Nominations for the UNESCO Masterpieces of the Oral and Intangible Heritage of Humanity, 2001-5.” In Laurajane Smith and Natsuko Akagawa (eds.), Intangible Heritage: 112-127. New York: Routledge.

Seitel, Peter, 2001a, "Proceedings of Smithsonian-UNESCO Conference Forthcoming." Smithsonian Talk Story 20: 13.

Seitel, Peter, 2001b, "Center's Participation in UNESCO Experts' Roundtable in Turin, Italy." Smithsonian Talk Story 20: 13-14.

Seitel, Peter (ed.), 2001c, Safeguarding Traditional Cultures: A Global Assessment. Washington: Smithsonian Center for Folklife and Cultural Heritage and UNESCO.

Serageldin, Ismail, 1998, "Culture and Development at the Millennium: The Challenge and the Response." Remarks at the opening of the Cultural Heritage Exhibition, World Bank, Washington, DC, September 28, 1998. http://documents.worldbank.org/curated/ en/1999/04/442079/culture-sustainable-development-investingcultural-natural-endowments (retrieved July 6, 2014).

Sherkin, Samantha, 2001, "A Historical Study on the Preparation of the 1989 Recommendation on the Safeguarding of Traditional Culture and Folklore." In Peter Seitel (ed.), Safeguarding Traditional Cultures: A Global Assessment: 42-56. Washington: Smithsonian Center for Folklife and Cultural Heritage and UNESCO.

Simon, Bradford, 2001, "Global Steps to Local Empowerment in the Next Millennium: An Assessment of the 1989 Recommendation on the Safeguarding of Traditional Culture and Folklore." In Peter Seitel 
(ed.), Safeguarding Traditional Cultures: A Global Assessment: 111-142. Washington: Smithsonian Center for Folklife and Cultural Heritage and UNESCO.

UNESCO, 1972, Convention Concerning the Protection of the World Cultural and Natural Heritage. Paris: Unesco. http://whc.unesco.org/ en/conventiontext/ (retrieved July 6, 2014).

UNESCO, 1989, Recommendation on the Safeguarding of Traditional Culture and Folklore, Paris, 15 October 1989. Paris: Unesco. http://portal.unesco. org/en/ev.php-URL_ID=13141\&URL_DO=DO_TOPIC\&URL_ SECTION=201.html (retrieved July 6, 2014).

UNESCO, 2003, "Impacts and Best Practices for Safeguarding Actions, First Proclamation of Masterpieces of the Oral and Intangible Heritage of Humanity." Unpublished manuscript CLT-2003/CONF.205/INF.7. Paris, 20 February 2003a.

UNESCO, 2003b, International Convention for the Safeguarding of Intangible Cultural Heritage, Paris, 17 October 2003b. http://www.unesco.org/ culture/ich/index.php?lg=en\&pg=00006 (retrieved July 6, 2014).

UNESCO, 2005, International Convention on the Diversity of Cultural Contents and Artist Expressions, Paris, 20 October 2005. Paris: UNESCO. http://www.unesco.org/new/en/culture/themes/cultural-diversity/ diversity-of-cultural-expressions/the-convention/convention-text/ (retrieved July 6, 2014).

UNESCO, s.d., "Intangible Heritage." http://www.unesco.org/culture/ich/ index.php?lg=EN\&pg=home (retrieved July 6, 2014).

Wendland, Wend, 2004, "Intangible Heritage and Intellectual Property: Challenges and Future Prospects.” Museum International 221/222: 97 106.

WIPO (World Intellectual Property Organization) Intergovernmental Committee, 2006a, "Draft Provisions on the Protection of Traditional Cultural Expressions/Folklore." http://www.wipo.int/tk/en/igc/draft_ provisions.html (retrieved July 6, 2014).

World Commission on Culture and Development, Javier Pérez de Cuéllar et al., 1997, Our Creative Diversity. Oxford: Oxford \& IBH Publishing/ UNESCO. 